\title{
CATV'S EMERGING ROLE: CABLECASTER OR COMMON CARRIER?
}

\author{
Chardes O. Verrill, JR.*
}

INTRODUCTION

Community antenna television (CATV) has grown in the past decade to an industry of such size and economic viability that, according to some forecasts, it poses a commercial threat to all but the strongest over-the-air or "free" television broadcast stations. In regulating CATV, however, the Federal Communications Commission (FCC), charged with the responsibility under the Communications Act of $1934^{1}$ of fostering the widest and most efficient use of communications and communications services, has been required to develop the regulatory policies considered necessary to accomplish its mandate without significant Congressional guidance. This article describes the forces that compelled the FCC, after an initial disclaimer of authority, to take jurisdiction over CATV and illustrates the enormous difficulties an administrative agency faces in the necessary application of old legislative tools and procedures to rapidly developing technology, particularly where an agency stepchild-here the UHF broadcast system-is threatened.

\section{Description OF CATV}

Community antenna television, known commonly by its acronym, CATV, is a facility which uses master antennas to receive television and FM radio signals broadcast by over-the-air television or radio stations, amplifies the signals so received, and distributes them by coaxial cable to the premises of its subscribers, who pay a fee for the service. Many systems now receive television signals by microwave radio relay or coaxial cable, which permits the importation of distant signals that could not be received by a high or master antenna. The typical CATV system consists of a "reception point," "headend," and "distribution system." At the reception point are located the towers, antennas, microwave receivers, and other equipment necessary to receive the program material off the air or from a microwave relay. The headend section consists of the equipment necessary to prepare the electronic signal for transmission over the distribution system, which consists of trunklines which originate at the headend and may be branched repeatedly to reach different sections of the system. The trunklines are connected to smaller cables which in turn are connected to the homes of individual subscribers.

\footnotetext{
*A.B. 1959, Tufts University; LL.B. 1962, Duke University. Member, Patton, Blow, Verrill, Brand \& Boggs, Washington, D.C.

${ }_{14} 4$ U.S.C. $\$$ I5I (1964).
} 
CATV systems were originally established in areas unable to support a local station or where the quality of television reception was poor or nonexistent because of intervening terrain, the curvature of the earth, or simply the distance from television broadcast stations. The first commercial CATV system was started in Lansford, Pennsylvania, in $1950 ;{ }^{2}$ by 1952 there were seventy systems; and as of January $\mathrm{I}$, I968, there were over 2,000 operating systems serving roughly three million subscribers (out of fifty-eight million U.S. television households), or one out of every seventeen television households in the United States. ${ }^{3}$ This growth has increasingly centered in communities with existing "free" television services, where interference from manmade obstructions such as multistory buildings or the need for strong signals unaffected by weather conditions for adequate color television reception have created a demand for improved service.

Early CATV systems were generally limited to a five-channel capacity and distributed only the signals of television stations that could be received by a tall antenna placed at a strategic location. Now, however, twelve-channel-capacity cables are common, and cables with twenty or even more channels are technically feasible. There is now also interest in the employment of CATV for a variety of other communications services:

If and when the projected potential of cable is realized, then we might have the third alternative ... that some farsighted people think they discern in our future. This would be based upon the concept of the home communications center, which would permit us to use electronic communications to accomplish many things we now do by other and perhaps less efficient methods. Thus we could have our daily newspaper printed in our home.... We could observe merchandise on a two-way television channel, place our order with a store, and direct the bank to credit the store's account and charge ours in payment-indeed, we could handle all our banking transactions by wire. Our children could have access to highly efficient teaching machines, and we and they could call on the accumulated memory and computational skill of a giant computer for a variety of purposes. The whole family could dial up a regional library center and have a book or magazine run off on our facsimile machine, or could select from a full range of video entertainment, both current and past, and have it displayed on our television set or fed into our home video tape recorder and stored for later use at our convenienceagain arranging for payment for this service by wire. We could even send a new form of mail by cable-if we haven't forgotten how to write in this whole process. All this, of course, in addition to many channels of television and nationwide picturephone service. ${ }^{5}$

2 I965 FCC ANN. REP. 78.

a ig68 FCC Ann. Rep. 46. See also Broadcasting, Apr. 7, x969, at iI3.

4968 FCC ANn. REP. 46.

- CATV and Interconnection of Telephone Devices-Where Do We Go From Here?, address by FCC Commissioner Kenneth Cox before the 8oth Annual Convention of the National Association of Regulatory Utility Commissioners, Nov. 13, 1968, at 9-10. A month later the Commission articulated much the same views in Amendment of Part 74, Subpart $\mathrm{K}$, of the Commission's Rules and Regulations Relative to Community Antenna Television Systems (Notice of Proposed Rule Making), No. I8397, 
A concomitant benefit of this communications structure would be the release of the UHF spectrum from the television broadcast allocation scheme with the result that those channels could be allocated to other uses, such as land mobile service, for which there are pressing requirements. ${ }^{6}$

The current, and even more the projected, role of CATV as a sophisticated broadband communications complex is far removed from what, in its inception, was considered a supplement to normal over-the-air broadcast service, which has long been viewed as the primary and most efficient mode of transmitting television signals to the public insofar as the FCC is concerned. ${ }^{7}$ In its early form CATV was not viewed as competitive with "local" and "free" television broadcasting; in fact, it was arguably a positive factor to those stations whose signal was made available in theretofore unserved areas. The Commission still occasionally relies on this latter argument when it suits the purpose of a given decision. ${ }^{8}$

It is now quite apparent, however, that the increasingly potent competitive potential of CATV, which has developed coincidentally with the first indications of prospects for UHF station profitability, stamps as unrealistic the supplementary role assigned CATV by the FCC. ${ }^{9}$ The new electronic technology and the requirements of a population desirous of receiving improved television in terms of both reception and the number of available signals necessarily require continuing policy review. The FCC has, in fact, already initiated such an undertaking, ${ }^{10}$ and has recently required that large CATV systems originate programming. ${ }^{11}$ At the same time, the FCC has continued to encourage the development of UHF over-the-air stations, a posture which has the appearance, if not the reality, of conflicting with the emerging CATV policy. In order to grasp the implications of this policy dilemma, it is, however, necessary to examine how a national communications policy grew up only to be supplanted by foreseeable but unforeseen technological developments.

II

\section{PatTerns of Growth: VHF, UHF, aNd CATV}

\section{A. VHF Growth}

CATV began at a time when commercial television was also an infant industry, and the FCC's policies had still not taken shape. A freeze on the grant of television

33 Fed. Reg. I9028 (F.C.C., released Dec. I3, I968) [proceeding hereinafter cited as CATV Amendments]. See also Barnett \& Greenberg, A Proposal for Wired City Television, in Communications and the Futture: A Symposium, r968 WAsH. U.L.Q. I (1968).

${ }^{8}$ Comments of Research Analysis Corporation, McLean, Virginia, at 4-5, CATV Amendments, supra note 5 (F.C.C., filed Feb. 19, I969).

${ }^{7}$ Pikes Peak Broadcasting Co. v. FCC, 422 F.2d 67r (D.C. Cir. r969), cert. denied 395 U.S. 979 (I969).

${ }^{8}$ See Paducah Newspapers, Inc. v. FCC, 414 F.2d II 83 (D.C. Cir. I969).

- On October 29, 1969, the FCC in effect reversed its view of CATV as a supplementary service by allowing program origination now and requiring it of larger systems by 197r. See CATV Amendments (First Report and Order), supra note 5, I7 P \& F RADio REg. 2d 1570 (1969).

${ }^{10} \mathrm{Id}$. (Notice of Proposed Rule Making).

${ }^{11}$ Id. (First Report and Order). 
broadcast station licenses was imposed in $194^{12}$ to permit the FCC to make major decisions about the structure of the broadcast industry. The freeze was lifted in 1952, with the issuance of a major allocation scheme for television facilities based upon five priorities (in descending order of importance): ( $\mathrm{I}$ ) one television service in all parts of the United States; (2) one station in each community; (3) a choice of two television services in all parts of the country; (4) two stations in each community; and (5) additional stations in larger communities. The guiding concept was local service, with the larger cities given a greater number of channels and new services. Because of its broader coverage at a given power, the Very High Frequency (VHF) band was the preferred spectrum. The lifting of the freeze resulted in large private capital investments in VHF facilities, and, by 1964, most of the 556 commercial VHF allocations had been awarded. ${ }^{13}$ Those in operation by that date had achieved, on the average, substantial profitability. ${ }^{14}$

\section{B. UHF Growth}

Considerably less dramatic was the growth of investment in stations broadcasting on the Ultra High Frequency (UHF) band following the FCC's initial UHF allocations in 1952 . The reasons for this are not difficult to discern. In I953 over twenty per cent of television receivers were equipped at the time of manufacture to receive UHF. By r96r, however, the percentage of receivers so equipped had declined to six per cent. In the aggregate, of the approximately fifty-five million television receivers then in the hands of the public in $196 \mathrm{r}$, only nine million, or sixteen per cent, were equipped to receive UHF, and presumably many of these sets were very old.15 The underlying reason for this manufacturing trend was the emphasis the three national networks placed on acquiring a full complement of VHF affiliates. ${ }^{16}$

By 1962 , when only 102 of the 1,544 authorized UHF stations were actually in operation, it had become obvious to the FCC and Congress that unless something were done to enhance the competitive posture of UHF, that portion of the spectrum would be wasted. Moreover, the FCC was committed to the view that "[u]se of all 82 TV channels (70 UHF as well as the 12 VHF) is necessary if the Nation is to

\footnotetext{
${ }^{12}$ Amendment of Section I.37I of the Commission's Rules and Regulations, Nos. 8736 \& 8975, I3 Fed. Reg. 5860 (F.C.C., released Sept. 30, I948).

${ }^{13}$ See generally M. Seiden, An Economic Analysis of Community Antenna Television Sxstems and the Televiston Broadcasting Industry 8-9 (1965). This study was commissioned by the FCC in July 1964 as part of its study of the CATV industry and has had, by many accounts, substantial influence on subsequent FCC policy formulation in this area.

${ }^{16}$ For example, total television industry income before federal income tax was \$416 million in 1964 , an increase of $21 \%$ over 1963 . 1965 FCC ANN. REP. I27. In 1967, while total industry income had slipped to $\$ 4 \times 4.6$ million, $83 \%$ of the full-time VHF stations on the air showed profits. Ig68 FCC ANN. REP. I23, I24.

${ }^{15}$ Senate Comm. on Commerce, Report on All-Channel Television Receivers, S. Rep. No. I526, 87th Cong., 2d Sess. 3 (Ig62).

10 President's Task Force on Communications Policy, Final Report ch. 7, at is (r968) [hereinafter cited as TASK Force Report].
} 
have fully adequate TV service."17 Therefore, in that year, the FCC urged Congress to pass the so-called All-Channel Receiver Act which was designed, according to its sponsors, "[to strike] at the root cause of the problem-namely, the lack of television receivers capable of receiving UHF signals."18 This legislation, by giving the FCC authority to require that all sets manufactured be capable of receiving all of the channels allocated for television use in both the UHF and VHF portions of the spectrum, was designed to permit maximum utilization of the broadcast spectrum, particularly of that assigned to UHF, which at that time was, by any measure, underutilized.

The passage of the All-Channel Receiver Act signified a Congressional ratification of the FCC's formulation of a national communications policy committed to the development of a full complement of operating UHF stations. ${ }^{19}$ This commitment, and the FCC's specific policy of relaxed regulation in the case of UHF, have encouraged private capital investments of huge proportions in new UHF television facilities. The cost of a fully equipped UHF station with high power and color capability will often exceed \$I million, and substantial losses are not uncommon in the first years of operation. ${ }^{20}$ Nevertheless, the number of operating commercial UHF stations increased from eighty-eight in 1964 to $\mathrm{x} 68$ in $\mathrm{I} 969_{2}{ }^{21}$ representing a substantial investment of private venture capital in reliance on stated public policies.

\section{CATV Growth}

In contrast to the responsiveness of Congress to the FCC's initiative to assist UHF as evidenced by the All-Channel Receiver Act, efforts by the FCC to obtain guidance from Congress on the objectives of public policy regarding CATV met absolutely no success. Despite the emergence of CATV as a significant, if auxiliary, service in the I950s, legislation to give the FCC broad authority over CATV was defeated in the Senate in 1959 by a single vote, and a more limited bill proposed by the FCC in $196 \mathrm{r}$ was not even reported out of committee. ${ }^{22}$ In fact, the Senate report on the All-Channel Receiver Act failed even to mention CATV. ${ }^{23}$ In retrospect, it seems clear that an opportunity in 1962 to plan and forge a communications policy for the future decades was lost through Congressional myopia.

The consequences of the 1962 decision to encourage investment in UHF are obvious: those who have committed capital in reliance on the policy to promote UHF development have an obvious claim to protection until their investment can be

\footnotetext{
${ }^{17} 1965$ FCC ANN. REP. TIO.

${ }^{18} \mathrm{~S}$. REP. No. 1526 , stipra note 15 , at 4.

10 "During the last ${ }_{5}$ years the Commission has made strenuous efforts to encourage the development of UHF to a point of parity with VHF, so that the nation can have a fully utilized television service." I968 FCC ANN. REP. 3I. For a critical discussion of the law and its effects, see Webbink, The Impact of UHF Promotion: The All-Channel Television Receiver Law, in this symposium, p. 535.

${ }^{20}$ See Ultravision Broadcasting Co., 2 P \& F Radio Reg. $2 d$ 27I (F.C.C., Apr. 4, 1964).

2138 Television Factbook 57-a (ig68); Brondcasting, Jan. 6, I969, at 72.

22 I965 FCC ANN. REP. 80-81.

${ }^{23}$ S. REP. No. 1526, supra note 15 . The Senate's version of the bill was ultimately adopted.
} 
recouped-indeed, until they can be assured a profitable operation. In a democratic society the government simply cannot induce private capital investments in reliance on government policies and then change those policies so abruptly as to destroy the investment. Yet, UHF broadcasting has not really been a success: in June r969, of the 298 commercial UHF allocations to the top roo markets, only xo5 were on the air..$^{24}$

CATV, on the other hand, is thriving for the most part and, notwithstanding its characterization by the FCC (until 1969 ) as a supplementary service, ${ }^{25}$ has enormous potential for the future, if the (according to its supporters) currently restrictive policies of the FCC are eased. The slow and halting progress toward achievement of the goals set for UHF and the potential of CATV as an additional rather than an auxiliary broadcast service have left the FCC with a national communications policy that seems at odds with economic and technical reality. The director of the FCC's CATV Task Force has lamented,

We were able to put men on the moon because there was relative singleness of purpose behind the program. But in cable regulation-which ought to be easy by comparison-the interested agencies in our society have not so far been able to agree on where the industry is going and what its role should be. ${ }^{26}$

There are now indications that the FCC has tentatively determined that this role should be as an additional service, but the process of reaching that decision has been characterized by indecision and policy reversals.

\section{III}

\section{Regulation of CATV Through ig68}

\section{A. Early Regulatory Activity}

The FCC first formally assessed CATV in April 1958, when it denied a petition by a group of television and radio broadcasters that it assert jurisdiction over CATV as a common carrier. ${ }^{27}$ The next month, an inquiry was initiated into the economic impact on TV broadcasting by CATV (Docket 12433), but the FCC terminated the proceeding in I959, concluding that it had no authority to take jurisdiction over

\footnotetext{
${ }^{24}$ TV Allocations and Channel Usage in Ioo Largest TV Markets as of May 3x, x969, FCC Release No. 33633 (June 10, 1969). Another indication of UHF broadcasting's slow progress is the fact that only $42 \%$ of the UHF stations on the air in 1967 operated at a profit. TV Broadcast Financial Data, FCC Release No. 26097 (Dec. 3I, I968).

as "[The Commission] holds that CATV service should be supplementary to and not cripple local TV broadcast service or impede the growth of TV broadcasting." I965 FCC ANN. ReP. 80.

${ }^{20}$ CATV-Utility or Not, address by Sol Schildhause before the Section of Public Utility Law, American Bar Association, Aug. 12, 1969, at $\mathrm{x}$.

${ }^{27}$ Frontier Broadcasting Co., 24 F.C.C. $25 \mathrm{I}$ (1958). This position has been reaffirmed in subsequent proceedings. Philadelphia Television Broadcasting Co. v. FCC, 359 F.2d 282 (D.C. Cir. I966); United States v. Southwestern Cable Co., 392 U.S. 157 (rg68). "The Commission and the respondents are agreed, we think properly, that these CATV systems are not common carriers within the maning of the Act." Id. at I69 n.29.
} 
CATV, and rejecting anew contentions that CATV should be regulated as a common carrier, that CATV systems are engaged in broadcasting, that CATV should be regulated because of an alleged adverse economic impact on broadcasting, and that it should take jurisdiction under its plenary power to implement the Communications Act. ${ }^{28}$ At the same time, the FCC requested authority from Congress to regulate CATV, but no legislation was enacted. ${ }^{20}$

After its initial refusal to assert jurisdiction, the FCC, in obvious response to the CATV threat to over-the-air broadcasting, has come virtually full circle. This effort began, modestly enough, with the Carter Mountain decision in 1962, when restrictions were placed on the activities of common carrier microwave facilities serving CATV systems. ${ }^{30}$ The following year, the court of appeals upheld the FCC's authority to refuse to license common carrier microwave facilities to serve CATV systems if the result would be deleterious to local television stations. ${ }^{31}$

Following its Carter Mountain decision, the FCC proposed rules to restrict the granting of licenses to private microwave stations serving CATV. Finding that the likelihood of CATV's adverse impact upon potential and existing service had become too substantial to be dismissed and that it was necessary to accommodate the conflicting interests of CATV and local broadcasting, the Commission adopted two rules. First, CATV systems served by microwave were required to transmit to their subscribers the signals of any station into whose service area they brought competing signals. Second, CATV systems were forbidden to duplicate the programming of such local stations for a period of thirty days (later reduced to fifteen) before and after a local broadcast. ${ }^{32}$

\section{B. FCC Assumption and Exercise of Broad Jurisdiction}

After several years of experience under these rules, the Commission in 1965 issued additional notices of inquiry by which it sought to determine whether all forms of CATV were properly the subject of regulation under the Communications Act. This initiative was in part caused by the release on March 5, 1965, of Dr. Martin $H$. Seiden's analysis of the economic relationships between television broadcasting and CATV. ${ }^{33}$ Seiden was unable to document any real evidence of direct adverse economic impact of CATV on TV, stating "CATV ... has not had a direct economic

\footnotetext{
${ }^{28}$ Impact of Community Antenna Systems, TV Translators, TV "Satellite" Stations, and TV "Repeaters" on the Orderly Development of Television Broadcasting (Report and Order), 26 F.C.C. 403 (I959) [proceeding hereinafter cited as CATV and TV Repeater Systems.] For a more detailed discussion of this proceeding, see Note, The Wire Mire: The FCC and CATV, 79 Harv. L. REv. 366, 369-70 (I965).

${ }^{20}$ See text accompanying note 22 supra.

${ }^{80}$ Carter Mountain Transmission Corp., 32 F.C.C. 459 (I962).

${ }^{81}$ Carter Mountain Transmission Corp. v. FCC, 321 F.2d 359 (D.C. Cir. I963).

${ }^{32}$ Amendment of Subpart L, Part 9r, to Adopt Rules and Regulations to Govern the Grant of Authorizations in the Business Radio Service for Microwave Stations to Relay Television Signals to Community Antenna Systems (First Report and Order), 38 F.C.C. 683, paras. 83-127 (1965) [proceeding hereinafter cited as CATV-Microwave Rules].

${ }^{83}$ SeIdEN, stupra note I3.
} 
impact on broadcasters." ${ }^{44}$ However, a very real future economic impact was projected, particularly on broadcasters in one and two station markets. ${ }^{35}$

Following extensive rule-making proceedings, the FCC in March rg66 adopted its Second Report and Order, which extended full jurisdiction to all CATV, in order "to avoid unreasonable competitive disadvantage and prejudicial effect on existing and potential broadcast service." 36 This goal was to be implemented by new rules which were viewed as "minimum measures [believed] to be essential to insure that CATV continues to perform its valuable supplementary role without unduly damaging or impeding the growth of television broadcast service."37 CATV was to be regulated, therefore, not because it is a common carrier service, or because it rebroadcasts television services, or because it is a broadcast service, but rather because, in the FCC's judgment, it posed a threat-if unregulated-to "free television." In order to neutralize this competitive threat, and to ensure the continued development of over-the-air television, the FCC concluded that it would be necessary to extend the carriage and nonduplication provisions of the First Report and Order to all CATV systems and to adopt a major-market/distant-signal policy.

\section{Carriage and Nonduplication Provisions}

The rg66 Rules required CATV systems (upon request and within the limits of channel capacity) to carry, without material degradation, the signals of all local television stations, in order of priority of signal grade, within whose grade $\mathrm{B}$ contours the CATV system is located. Under this scheme, the CATV system was primarily required to carry signals of those stations which placed a grade $A$ contour $^{38}$ into the system city, and finally, if there were channel availability, the signals of stations whose grade $B$ signals reached the system city. These requirements were modeled after the rules that were previously adopted for CATV systems served by microwave and have never stirred substantial controversy.

The nonduplication provisions required a CATV system, upon request of a local station, to avoid duplication on the system by carrying the same program on a distant station during the same day that the program was broadcast by the local station. $^{39}$ Special rules were adopted in the case of network prime-time program-

${ }^{38} \mathrm{~A}$ contour is defined as "a line drawn on a map connecting points of equal signal strength broadcast from a given transmitter. ... On the grade $\mathrm{A}$ contour of any television station a minimum of 70 percent of the viewing locations, with an outdoor antenna 30 feet high, may expect good to excellent reception for 90 percent of the time." I968 FCC ANN. REP. 156. In the grade B contour, signal strength is measurably less.

${ }^{30}$ The fifteen-day "before and after period" specified in the First Report and Order was abandoned after a determination that "simultaneous nonduplication protects the bulk of the popular network programing of most network affiliates and does not affect the time that such programing is available to the CATV subscriber." CATV-Microwave Rules (Second Report and Order), supra note 36, para. 51 .
} 
ming, and no duplication protection was afforded to programs carried in black and white by local stations and carried in color by a more distant station on the CATV system. However, the Commission did give notice that it would grant greater degrees of protection and waivers of the rules in special cases if a convincing case, based on economic injury, could be made.

These requirements were premised on the arguments that ( $I$ ) the failure to carry local stations on a CATV system, and duplication of their programming by carrying stations from other markets with the same programming, constitute unfair competitive practices which are inconsistent with the supplementary role assigned to CATV, and (2) these requirements were necessary to ameliorate the risk that the burgeoning CATV industry would have a future adverse impact on television broadcast service. The critical factor in this analysis is the Commission's determination in Ig66 to commit CATV to a supplementary role and to make certain that it did not replace over-the-air free television service. This concept is the key to an understanding of the entire pattern of CATV regulatory development.

\section{Major-Market/Distant-Station Policy}

A weakness of a nonduplication requirement is that it protects, in practical fact, only network affiliates, since it is unlikely that a local station and a distant station would carry the same syndicated program on the same day. Yet it is the independent station that is most in need of protection because of the small share of the audience available to it. The major-market/distant-station policy adopted in Part Two of the Second Report and Order dealt with both this problem and that of how much to mesh the development of UHF with the increasing availability of multichannel CATV systems. The basic question raised by the FCC was whether it is fair to permit a CATV system to "import"-that is, bring in from other citiestelevision signals to offer to local viewers, thus increasing substantially the number of services available but, at the same time, "splintering" the audiences of independent stations:

There is no doubt as to the seriousness of the question posed. The new UHF stations face a difficult road; we would expect, with the passage of time and thus the build-up of all-channel sets, and related endeavors, that these new operations would be successful. But if a CATV, with 12- or 20-channel capacity, can obtain very substantial numbers of subscribers in these same markets (by which we mean percentages of 50 percent or over), the UHF stations might face a very difficult hurdle. The audience for nonnetwork stations is limited (about a ro-percent share in most markets in the prime time) and this limited audience might be greatly reduced since very substantial numbers of people interested in viewing the nonnetwork programing would be watching the distant independents (e.g., those of New York or Los Angeles). We think this follows as a matter of commonsense, since these established big city VHF independents certainly have the ability to bid for and acquire the expensive, attractive nonnetwork programing. ${ }^{40}$

\footnotetext{
${ }^{10}$ Id. para. 123.
} 
To permit the unlimited expansion of CATV services that include imported signals of independent stations, with its likely effect (as viewed by the FCC) on local independent UHF stations, would be, the FCC concluded, inconsistent with the obligation to promote the larger and more effective use of the radio spectrum. While the audience would have a greater selection of signals, all with uniform picture quality, local programming would be sacrificed. The demise of local independent UHF would be detrimental to the public interest because "Congress and the American public have staked a great deal on the development of UHF."41 CATV had, in the FCC's I966 view, three basic faults that made it an unacceptable alternative to $\mathrm{UHF}:^{42}$

(I) CATV does not serve rural areas because the cost of extending the wires in unpopulated areas is prohibitive. This is a point almost all commentators agree on and is an aspect of CATV that would be difficult to resolve unless Congress sheds its reluctance to grapple with the problems of communications policy or a totally new approach to CATV regulation is adopted.

(2) CATV is a form of "pay-TV" in that subscribers must pay a fee for the service, and there are probably people who either do not want to or cannot afford to pay for television.

(3) CATV does not serve as an outlet for local expression.

The first two of these objections are economic, and the third was a makeweight: indeed, one very real potential for CATV is the fact that it can provide far more local outlets at substantially less cost than is conceivable under even the most optimistic projections for UHF. (The Commission's recent adoption of program origination requirements for CATV systems suggest that this logic has prevailed.) A more persuasive argument for the distant-signal policy is found in the discussion of fair competition in the Second Report and Order. According to the FCC, it is "unfair competition" for a CATV system in Detroit to "import" independent station signals from Milwaukee and to carry them in competition with the programs of independent Detroit stations. The latter typically bargain for their nonnetwork programs, pay a fee for their use, and generally obtain an exclusive right to their use in the geographic area. Moreover, section 325(a) of the Communications Act prohibits any station from "rebroadcasting" programs without the originating station's consent. ${ }^{43}$

CATV, by importing distant signals, disrupts this orderly distribution pattern: First, CATV has been held not to be a broadcast service, and therefore it is not subject to the rebroadcast provisions of section $325(\mathrm{a}) .{ }^{44}$ Second, the CATV system imports distant signals without paying for the material and thus increases its ability

\footnotetext{
${ }^{11} I d$. para. II 4 .

12 Id. para. 124.

437 U.S.C. $\$ 325(\mathrm{a})(1964)$.

"CATV and TV Repeater Systems, supra note 28.
} 
to compete without cost. Third, the local station cannot, because of section $325(\mathrm{a})$, use a high antenna or microwave to do what the CATV does. "Unfair competition" occurs when broadcasts of sports events are blacked out on the local station but carried on stations in nearby communities. If the local CATV is permitted to import the broadcast of the event, then it is unfairly competing with the local station that cannot.

On the basis of these considerations the FCC adopted a procedure whereby the signal of a television broadcast station may not be extended beyond its grade $B$ contou $x^{45}$ into the top roo markets (as determined by the principal market rating organization) by a CATV system which has obtained a franchise for operation in such a market, except upon a showing made in an evidentiary hearing that operation with distant signals would be consistent with the public interest and particularly with the establishment and healthy maintenance of UHF television broadcast service. $^{46}$ The FCC was convinced that this procedure would enable it to explore in depth the economic impact of CATV importation of distant signals into the major markets. The top roo markets were selected because they are where UHF is most likely to develop, whereas the smaller markets are where CATV could make a particularly significant contribution. As the FCC viewed its action, "the market division which we adopt is really a division between CATV in its traditional sense and the new, revolutionary facet of CATV, as posed by its entry into the major markets." ${ }^{\text {"47 }}$

Since the Second Report and Order was a contradiction of prior FCC determinations that it lacked jurisdiction, it was inevitable that review by the Supreme Court would be sought. The case that eventually reached that court was initiated by Midwest Television, Inc., licensee of KFMB-TV, San Diego, California (the fifty-fourth largest market), which petitioned the FCC for relief under sections 74.IIO7 and 74.Irog of its rules, contending that the San Diego CATV systems imported distant (Los Angeles) signals and that this had an adverse effect on KFMB-TV. After lengthy proceedings but without any hearing on the merits of these contentions, the FCC limited the San Diego CATV systems to carriage of those signals carried on the date the Second Report and Order was proposed. ${ }^{48}$ The Court of Appeals for the Ninth Circuit set aside this order, holding that the FCC lacked authority to issue it, but the Supreme Court reversed this decision. ${ }^{40}$

The Southwestern Cable case does not give the FCC a mandate to regulate CATV as a broadcast service, as a common carrier, or even as communications by

\footnotetext{
45 "On the grade B contour of any television station a minimum of 50 percent of the viewing locations, with an outdoor antenna 30 feet high, may expect satisfactory reception for 90 percent of the time." I968 FCC ANN. REP. I56.

However, those systems in operation with imported signals prior to the issuance of the proposed rule were "grandfathered."

"CATV-Microwave Rules (Second Report and Order) supra note 36, para. I45.

${ }^{48}$ Midwest Television, Inc., 4 F.C.C.2d 6r2 (1966).

${ }^{6}$ United States v. Southwestern Cable Co., 392 U.S. 157 (I968), rev'g Midwest Television, Inc. v. Southwestern Cable Co., 378 F.2d II 8 (gth Cir. I967).
} 
wire. On the contrary, despite broad language about the FCC's authority and powers under the Communications Act, the Court expressly disclaimed any intention "to determine in detail the limits of the Commission's authority to regulate CATV." ${ }^{\circ 0}$ Rather, the FCC's authority to issue the order appealed from derived from section 152 (a) of the act, which authorizes the adoption of such measures as are "reasonably ancillary to the effective performance of the Commission's various responsibilities for the regulation of television broadcasting." ratified the FCC's decision to take jurisdiction on the basis of the probable impact of CATV on UHF broadcasting, a rationale wholly consistent with the characterization of CATV as a supplementary service.

The distant-signal policy of the Second Report and Order (section 74.IIo7(d) of the FCC Rules and Regulations) contemplated that a CATV system that proposed to operate with distant signals in one of the top roo markets could not commence operations until it had established in an evidentiary hearing that importation was consistent with the establishment and healthy maintenance of local TV broadcast service. A large number of section 74.IIO7 requests were set for hearing (hearing waivers were granted in many other cases), and one which was finally decided, Midwest Television, Inc., ${ }^{52}$ has achieved special prominence. This proceeding established to the satisfaction of the FCC that CATV penetration in the major markets (the "revolutionary new role" of CATV that was predicted in the Second Report and Order) would be substantial (up to fifty per cent of TV homes), that this penetration would likely be harmful to UHF development, that unfair competition would be significant, and that it would frustrate the allocations policy for one market to become, due to imported CATV signals, a mere satellite of another.

Given the extraordinarily difficult problem of developing policy to accommodate public and private interests in the increasingly complex communications industry, the Second Report and Order was generally a very successful effort in that it resulted in (I) the "hard" evidence of CATV impact in the Midwest proceeding, and (2) a Supreme Court decision affirming FCC jurisdiction. In its specifics, however, there were significant weaknesses, which were articulated by FCC Commissioner Cox in November 1968 :

Our carriage and non-duplication rules have worked reasonably well--though we have not gotten around to enforcing them everywhere as yet. But our distant signal policy is in a shambles. Our staff is swamped with petitions for waiver of the rule and we have a substantial backlog. In acting on these requests, a majority of the Commission-over my protests-have granted waivers which have permitted importation of distant signals for systems well within the Grade A contours of stations which the rule was designed to protect-but have done so in a confusing and completely inconsistent way. ${ }^{53}$

\footnotetext{
${ }^{\text {50 }} 392$ U.S. at 178 .

"1d.

${ }^{53}$ Midwest Television, Inc., I3 F.C.C.2d 478 (I968).

${ }^{53}$ Cos Address, supra note 5, at 3.
} 
A general frustration with the major-market/distant-signal policy, together with a conviction on the part of the FCC that it was necessary to undertake yet another attempt to formulate policy, led to the issuance on December 13, I968, of a new notice of inquiry entitled Community Antenna Television Systems-Development of Communications Technology and Services. ${ }^{54}$ This proceeding, according to the FCC, was designed

to explore the broad question of how best to obtain, consistent with the public interest standard of the Communications Act, the full benefits of developing communications technology for the public, with particular immediate reference to CATV technology and potential services, and the nature of any regulations and/or proposed legislation that may be necessary or desirable to further this goal. ${ }^{65}$

The December r $3^{\text {th }}$ Notice of Inquiry caused a storm of protest, particularly by the CATV industry, which viewed the proposals as intended to destroy CATV or at least freeze its further development. The former chairman of President Johnson's Task Force on Communications Policy told the American Management Association in a speech that the FCC's actions in the Notice were inconsistent with its professed goals and that it had "ordered what is for all practical purposes a standstill in the industry for an indefinite period."56 The FCC even received complaints that its Notice of Inquiry had caused layoffs at a company that manufactures CATV equipment. ${ }^{57}$ And the following spring the President of the National Cable Television Association (and a former FCC member) declared to Congress that the "CATV industry has no confidence in the desire, willingness or the ability of the Federal Communications Commission, as presently constituted, to conduct a fair and impartial hearing on cable television or to regulate it in the public interest" and recommended that the regulation of cable television be transferred to the Department of Commerce. ${ }^{58}$ Analysis of the December 13th Notice, the interim procedures adopted, the proposed rules, and the subsequently adopted program origination rules suggests a different evaluation.

The Notice really has two tones: one reflects an awakening realization that CATV may in the final analysis have the potential of being the most important of all video communications modes. Thus, the preamble quotes extensively from the transmittal letter that accompanied a September 1968 report to the Mayor of New York on CATV and which characterized the promise of CATV as "glittering." The Notice also acknowledges the potential of the wired city:

The so-called "wired city" concept embraces the possibility that television broadcasting might eventually be converted, in whole or in part, to cable transmission

\footnotetext{
${ }^{54}$ CATV Amendments (Notice of Proposed Rule Making), supra note 5.

${ }^{55} I d$. para. 2.

${ }^{86}$ CATV Finds Two Important Friends, Broadcasting, Mar. 17, 1969, at 146.

${ }^{67}$ Letter from Robert V. Cahill, Legal Assistant to FCC Chairman Rosel Hyde, to Local 158, United Electrical, Radio and Machine Workers of America, Jan. I7, 1969.

${ }^{58}$ Statement of NCTA President Frederick W. Ford before the Subcomm. on Communications and Power of the House Comm. on Interstate and Foreign Commerce, May 20, 1969, at 38, 39 (mimco.).
} 
(coupled with the use of microwave or other intercity relay facilities), thereby freeing some broadcast spectrum for other uses and making it technically feasible to have a greater number of national and regional television networks and local outlets. ${ }^{\text {.9 }}$

The FCC, of course, is not likely to soon embrace this concept, which involves such a radical departure from earlier national policy choices.

The interim procedures and proposed changes in the regulations strike a different note. If adopted in full, the proposals would require adjustment of operating modes in the CATV industry and would continue the devices incorporated in the Second Report and Order to protect UHF (and particularly independent UHF stations) from unfair competition. These proposals resulted in a bewildering variety of responses but have yet to be finalized except to the extent that CATV systems have, under certain conditions, subsequently been required to originate programming. Pending resolution of the rule making announced in the Notice, the FCC halted all hearings in all top roo market proceedings wherever they stood on that date. However, petitions for waiver of hearing would still be entertained where the proposed operation would be outside the thirty-five mile zone proposed as part of the new distantsignal policy. Also, systems inside those zones could petition to commence operations with retransmission consent. Finally, systems in operation on the date of the Notice (December I3, I968) were "grandfathered" "in order to avoid substantial disruption to the CATV subscribers." 60

The distant-signal policy was a major-innovation of the Second Report and Order, and the December I $3^{\text {th }}$ Notice would preserve this policy in the top roo markets. However, the evidentiary hearing procedure would be replaced by a definite rule to determine when distant signals could be imported based on the location of the CATV systems ${ }^{\text {01 }}$ and the obtaining of "retransmission consent" from the originating station. In adopting this proposal, the FCC reiterated the unfair competition rationale in the clearest terms yet enunciated:

Namely, the UHF station has no protection against duplication by CATV systems bringing in distant signals of its film programing upon which it depends for an adequate economic base to serve as an outlet for local expression .... And, even more important, both the CATV system and the broadcast station are large scale operations competing for audience-yet the one pays for its product and the other, without any payment, brings the same material into the community by simply importing the distant signals. ${ }^{62}$

${ }^{\circ 0} \mathrm{CATV}$ Amendments (Notice of Proposed Rule Making), stipra note 5, para. 9.

${ }^{\circ}$ Id. para. 53 .

${ }^{01}$ In the hearings and waiver of hearing request proceedings pursuant to the Second Report and Order, stipra note 36 , the station's predicted grade A contour had been the measure for determining the area in which the distant-signal policy applied. In the inquiry announced December 13, 1968, the FCC proposed substituting a fixed mileage standard consisting of the area within a 35 -mile radius of the main post office in each major market. CATV Amendments (Notice of Proposed Rule Making), supro note 5 , para. 48 .

${ }^{05}$ CATV Amendments (Notice of Proposed Rule Making), stipra note 5, para. 35. 
Significantly, the FCC deliberately eschewed any finding that CATV use of distant signals would destroy or even cripple UHF. Rather, the FCC relied on the assumption that the "unfair competition" of CATV "will be a significant factor in the development or healthy maintenance of television broadcast service," and that this unfair competition "should be eliminated under the public interest standard of the Communications Act." ${ }^{33}$ In the absence, however, of unfair competition, CATV should be permitted to compete with traditional broadcast services.

Having isolated the element of CATV operation that is viewed as having the most likely impact on UHF-the importation of distant signals-the FCC decided that the best way to eliminate this "element of unfair competition" would be to adopt a rule permitting distant signals to be imported but requiring that those CATV systems operating in major markets (the top roo) obtain the consent of the distant station to the transmission of its signal into another market. Presumably, this consent would entail a payment of some kind, since if such consents were freely given, the element of unfair competition would not be eliminated. In fact, it might be exacerbated if independent VHF stations, with superior programming were to begin to look upon distant markets as having potential because of the prospect of prosperous CATV systems seeking their programs.

The "retransmission consent" proposal raised the question whether the FCC was attempting to apply the copyright law to CATV administratively and thus sidestep the decision of the Supreme Court in Fortnightly Corp. v. United Artists Television, Inc., ${ }^{64}$ which held that CATV is not subject to the copyright act ${ }^{65}$ because CATV does not "perform" the copyrighted material-rather it falls more in the category of a "passive beneficiary," much like the home viewer who erects an antenna to improve the signal. ${ }^{66}$ Observing that Congress should really settle the issue, the FCC rationalized the retransmission consent concept as analogous to the rebroadcast provisions of section 325 (a) of the Communications Act. ${ }^{67}$ If a local UHF station has to obtain consent to rebroadcast the program of a distant station, then, reasoned the FCC, so should CATV. One difficulty with this analysis is that section $325(a)$ is not limited to rebroadcast of distant station signals: "nor shall any broadcasting station rebroadcast the program or any part thereof of another broadcasting station without the express authority of the originating station."

\footnotetext{
${ }^{63}$ Id. para. 36.

es Fortnightly Corp. v. United Artists Television, Inc., 392 U.S. 390 (1968).

${ }^{\circ}$ For a discussion of the CATV/copyright controversy, including the various legislative proposals, see Comment, CATV-The Continuing Copyright Controversy, 37 FordusM L. Rev. 597 (1969).

${ }^{60} 393$ U.S. at $399-400$.

67 "Specifically, the Commission proposed to eliminate the unfair competition aspect by a proposed rule which would permit CATV systems to carry distant signals . . . only if the system has the express authorization of the originating stations .... Such a rule would parallel the broadcast consent provision of section 325 (a) of the Communications Act . . . Statement of FCC Chairman Rosel Hyde before the Subcomm. on Communications and Power of the House Comm. on Interstate and Forcign Commerce, May I9, 1969 , at II (mimeo.).

${ }^{08} 47$ U.S.C. $\$ 325(a)(1964)$.
} 
purpose of section 325 (a) is obviously to prevent "pirating" of one station's product by another station, no matter where located. In this context, a logical argument could be made that any CATV system that uses the signal of any broadcast station should obtain its prior consent.

The major difficulty with the retransmission consent interim standard proposed is, however, a practical one. The interim rules require that CATV systems obtain retransmission consent on a program-by-program basis. Since most stations do not own the programs they transmit, the retransmission rights the Commission envisions cannot realistically be given. What has resulted, therefore, is a "freeze" on new importations of distant signals by CATV systems into the top too markets (those being carried on the date of adoption of the December I3th Order were "grandfathered"). As described by the Director of the FCC's CATV Task Force:

What is happening, of course, is that more time is being bought for the contending forces to work out the complicated copyright negotiations. And so I do not for the near-term look for much, if any, change in the 35-mile stalemate until the outlook for early copyright settlement clarifies. ${ }^{69}$

No agreement has been reached on this question, and one seems remote at this point. $^{70}$

The effect of the practical freeze on new importations becomes more important in the context of the FCC's conclusion in the December I 3 th Notice that CATV program origination is in the public interest and should be encouraged. Cable technology has the potential to further the achievement of long-established regulatory goals in the field of television broadcasting by "increasing the number of local outlets for community self-expression and for augmenting the public's choice of programs and types of service ...."71 The Notice also expressed the Commission's belief that the public interest would be served by encouraging CATV systems to operate as common carriers on some channels in order to afford an outlet for others to present programs of their own choosing.

Based on these tentative conclusions and the responses received to the Notice, the Commission on October 27, I969, issued its First Report and Order in Docket I8397, ${ }^{72}$ which established new rules regarding program origination and the standards cable systems would be required to adhere to in their programming. This document, while leaving a number of questions open for later decision, marks the FCC's first move toward allowing CATV something more than a role supplementary to over-theair broadcasting.

\footnotetext{
${ }^{\circ}$ Schildhause address, stipra note 26 , at 5 .

${ }^{70}$ An agreement between NAB and NCTA reached in May 1969 was repudiated by the members of $\mathrm{NAB}$ and has not yet been revived.

${ }^{71}$ CATV Amendments (Notice of Proposed Rule Making), supra note 5, para. 13.

${ }^{72}$ CATV Amendments (First Report and Order), supra note 9.
} 


\section{The rg69 First Report and Order}

The rules adopted in the First Report and Order of October 27, 1969, provide, first, that on and after January $\mathrm{x}$, 197I, no CATV system having 3,500 or more subscribers may carry the signals of any television broadcast station unless the system also operates to a significant extent as a local outlet for "cablecasting" (the term coined by the FCC to describe CATV program origination) and has available facilities for local production and presentation of programs other than automated services. Second, no CATV system shall carry the signals of any television broadcast station if the system engages in cablecasting, unless such cablecasting is conducted in accordance with rules adopted regarding cablecasts by candidates for public office, the fairness doctrine, personal attacks, and political editorials. Third, any CATV system engaged in cablecasting may present advertising material provided that it is carried only at the beginning and conclusion of programs and at natural intermissions or breaks within the cablecast. Finally, the new rules provide that the sponsors of programs carried on cable and originated by it shall be identified.

Aside from these specific rules, the Order encourages cablecasting by all CATV systems and urges that all cable systems make available one or more channels for common carrier usage. The Commission left for later discussion and decision the questions whether cable operators would be prohibited from cablecasting on more than one channel, whether advertising should eventually be permitted in conjunction with the possible emergence of a CATV network operation, and what rules should govern common ownership of CATV and other media in the same markets.

\section{A. Program Origination}

\section{x. Requirements}

To achieve its objective of increasing the number and variety of program services available, the Commission concluded that it would permit the carriage of broadcast signals by large CATV systems only on the condition that the system "operate to a significant extent as a local outlet by originating" programming, that is, cablecasting. ${ }^{73}$ The rationale for this awkward approach to regulatory assertion of jurisdiction is that "the use of broadcast signals has enabled CATV to finance the construction of high capacity cable facilities." ${ }^{174} \mathrm{~A}$ second reason for the origination requirement is that it will require CATV operators to have available origination facilities which can be utilized by persons who lease the channels which are devoted

${ }^{73}$ Id. para. 15. The Commission did not define the phrase "operate to a significant extent as a local outlet by originating," but it did indicate that this required more than the origination of automated (e.g., time and weather) and aural (e.g., music) services. Moreover, "since one of the purposes of the origination requirement is to insure that cablecasting equipment will be available for use by others originating on common carrier channels [this] in essence necessitates that the CATV operator have some kind of video cablecasting system for the production of local . . . programming . . . " Id. para. 29.

"Id. para. I9. 
to common carrier usage: "We think that this is necessary as a practical matter if the public is to take advantage of any common carrier offering on a widespread basis."75 This formulation fully complements the unfair competition rationale of the distant-signal policy, since it applies only to the larger systems (which are more likely to fragment over-the-air audiences), requiring these systems to begin competing on their own with over-the-air independent and network programming while at the same time continuing the limitations on their importation of distant signals.

The Commission acknowledged that, while the public need for local origination may be greatest in small CATV communities, such systems may be so small as to render the origination of programming or the construction of facilities for the use by others on the common carrier channels economically prohibitive. Because the Commission lacked adequate information as to the cable systems that would be able to support local origination, it elected to use as a cutoff point the total of $3,5^{00}$ subscribers, making clear, however, that "the Commission intends to obtain more information from originating systems about their experience, equipment and the nature of the origination effort. ... In the meantime, we will prescribe a very liberal standard for required origination, with a view toward lowering this floor in the further proceedings, should the data obtained in such proceedings establish the appropriateness and desirability of such action."76

The Commission's preoccupation with permitting "fair" but not "unfair" CATV competition, and the public interest rationale of this position, are evident from the diposition of the broadcasting interest contention that origination should be prohibited or severely limited. In effect abandoning the strictly "supplementary" role of CATV, the Commission concluded,

[I]f the public is to be provided with additional program choices and different types of services and chooses to take advantage of them, it appears inevitable that there may be less viewing of the previously existing services. However, we do not think that the public should be deprived of an opportunity for greater diversity merely because a broadening of selections may spread the audience and reduce the size of the audience for any particular selection. Such competition for audience attention is not unfair, since broadcasters and CATV originators ... stand on the same footing in acquiring the program material with which they compete. ${ }^{77}$

Thus, the Commission has begun to recast the CATV role from an auxiliary service to something approaching an additional service.

\section{Economic Basis for Origination}

In order to establish an economic basis for the new CATV role, the Commission concluded that advertising should be permitted at natural breaks in originations

\footnotetext{
${ }^{75} I d$. para. 20.

${ }^{70}$ Id. para. 26.

${ }^{77}$ Id. para. 5 .
} 
with no interruption of program continuity. This general policy is designed to contribute to the financing of local origination and installation of equipment. While broadcasters generally opposed the allowance of advertising on CATV, the Commission rejected their attack on the ground that the public interest does not require that one economic interest be favored over another, and that economic detriment will only be considered a relevant policy factor where the result would be a diminution of services to the public. Second, the comments in response to the December r $3^{\text {th }}$ Notice led to the view that

existing CATV rates are much more analogous to typical radio rates than they are to those of television stations generally, or UHF independents in particular. It would seem to follow that CATV advertising on comparatively small systems poses a greater possibility of adverse impact on the revenues of radio stations than on those of television stations. ${ }^{78}$

While not oblivious to the potential of CATV to compete with television, the Commission relied on its objective of providing new and diversified services as a justification for possible economic detriment.

\section{B. Equal Time, Fairness, and Sponsorship Identification}

The Commission concluded that in view of its determination not to prohibit but rather to encourage CATV origination and to permit advertising it was necessary to adopt rules with respect to equal time, fairness, and sponsorship identification analogous to those currently applicable to broadcasters. ${ }^{70}$ These rules are a natural extension of the Commission's jurisdiction in view of the origination proposals and were justified on several grounds. First, if a cable system were allowed to cablecast on one or more channels and did not observe the equal time, fairness, or sponsorship identification doctrines the public would receive a distorted view since the television broadcasting which is carried by the system would be subject to those requirements. Morever, the Commission concluded that its action in this respect was "reasonably ancillary to the effective performance of the Commission's various responsibilities for the regulation of television broadcasting." 80 Finally, because CATV systems use broadcast signals as the backbone of the service they provide, they come within the regulation of the agency since the requirements are reasonably related to the public interest.

\section{V}

\section{Evaluation}

Having analyzed the context of the development of CATV regulation, it is difficult to understand the CATV industry position that "[the FCC] has taken no

\footnotetext{
${ }^{78}$ Id. para. 36.

${ }^{79}$ See generally Loevinger, Free Speech, Fairness, and Fiduciary Duty in Broadcasting, in this symposium, pt. I, p. 278 .

${ }^{80}$ CATV Amendments (First Report and Order), stipra note 9, para. 45, citing United States v. Southwestern Cable Co., 392 U.S. 157, I7 $_{8}$ (1968).
} 
meaningful action to fit this industry into the electronic mass communications complex, nor has it announced any plans for the 'Full Development of CATV'-only one proposal after another, and one ruling after another to restrict, harass and contain it." ${ }^{\prime 1}$ There is truth to the view that the FCC took jurisdiction over CATV, in part, to protect UHF; but then, what was the Commission to do? ${ }^{82}$ It had Congressional approval of its policy in seeking full utilization of UHF allocations, and Congress declined to give it guidance on how to undertake CATV regulation. Had the FCC maintained its early posture on CATV and had UHF been destroyed as a viable segment of the communications mix, the FCC surely would have been charged with administrative nonfeasance. A Commission official has, in fact, stated, "Without rehashing published justifications for the [CATV] program, I would observe that a couple of generations of investment and experience in broadcasting count for something, and the reluctance to run the risk of undercutting the structure is understandable." ${ }^{.83}$

It seems unarguable that a mixture of over-the-air television and CATV is, for the foreseeable future, essential. President Johnson's Task Force on Communications Policy, in a report adopted on December 7, xg68 (but not released until May I969), lamented the failure of television to achieve the diversity of other media (such as magazines) and stated that cable television offered one promising avenue to this diversity, although unregulated expansion could involve serious social costs. The report further argues that current over-the-air television service is limited by high costs and limited revenue potential. The common argument that limited spectrum space limits the number of services is largely fallacious: in fact, the limitation on the number of over-the-air services is most often economic. Thus, multi-channel cable holds promise, as the FCC also clearly recognizes, as an additional service. But the cost of totally substituting CATV for the present system would be too high: for example, a study made for the Task Force indicated that the cost of "wiring up" the country would be prohibitive. The report concludes that an accommodation between the goal of allowing the development of a multichannel capability CATV and the benefits of preserving adequate over-the-air service is among the most important challenges to public policy in the field of broadcasting. ${ }^{84}$ It is precisely this accommodation that the FCC seems to be seeking in its most recent pronouncements.

\footnotetext{
${ }^{81}$ Ford Statement, supra note 58 , at 29. The CATV industry does, however, support H.R. I05I0, a bill introduced in the current Congress which would give the FCC authority "to issue rules and regulations to (I) require the reception of television broadcast station signals within whose established reception area any such system is located; (2) to maintain the station's exclusivity as a program outlet against simultaneously duplicating signals from stations whose signals are distributed beyond their established reception areas; (3) to establish reasonable technical standards and reporting by CATV systems; and (4) authority to require the deletion of distant signals upon a finding that a local station was failing as a direct result of such reception and distribution of such distant signals." Id. at 36.

${ }^{82}$ For an answer which does not treat this as a rhetorical question, see Webbink, supra note r9.

${ }^{83}$ Schildhause address, supra note 26 , at 3 .

${ }^{84}$ See TASK FORCE REPORT, supra note I6, ch. 7 .
} 
An Alternative for Long-Term Policy Making

In this bedeviling context, in which there have been no really innovative alternatives offered to the FCC's proposals, it seems likely that the immediate future of CATV regulation will follow this pattern:

We stir, move ahead a step, go sideways for a while, back and fill, re-examineall the while groping for a permanent policy. And I look for no great leaps forward. What we will live with for a long time is a continuing series of small skirmishes, most of which will be settled by some kind of regulatory reaction to the necessities of the moment. From it all, over a period of years will hopefully emerge the pattern that will permanently stamp dimensions and direction..$^{85}$

This difficulty of a regulatory agency in attempting to cope with technological change in an industry, particularly where Congress fails to give any significant guidance, is perhaps inevitable. However, the preamble to the December 13th Notice, and especially the request for comments in Part Five, suggest that the FCC is now willing to consider how it can accommodate radical change within the context of the Communications Act of 1934 .

All of the Commission's pronouncements on CATV have been characterized by caution: Indeed, it has taken a decade for it to assert jurisdiction on the basis that "in authorizing the receipt, forwarding and delivery of broadcast signals, the Commission is in effect authorizing CATV to engage in radio communication." ${ }^{.80}$ This approach was and is justified by the need to avoid disruption of established patterns of communication, the moral if not legal responsibility to prevent financial distress to those who had invested in UHF in reliance on older Commission policies, and by the failure of Congress to provide policy guidance. These problems should not, however, preclude development of a long-term policy objective.

In the Ig68 Notice of Inquiry (Docket 18397) the FCC reached the tentative conclusion that CATV operators should operate as common carriers on at least some channels. This would, according to the Notice, provide a program outlet for persons not regularly engaged in broadcasting. The First Report and Order reaffirms this conclusion in broad terms:

We also deem it appropriate at this time to amplify our view that CATV systems should be encouraged, and perhaps ultimately required, to lease cable space to others for originations of their own choice on a local or interconnected basis, in order to promote diversity of control over the media of communication and diversity of program choices as well as to increase the opportunities for television communication with the public by more widespread sources. We adopt no rules at this time, since this is an area which we believe requires further study and analysis of the comments. ${ }^{87}$

\footnotetext{
${ }^{85}$ Schildhause address, stspra note 26 , at 3 .

${ }^{86}$ CATV Amendments (First Report and Order), supra note 9, para. 20.

${ }^{87}$ Id. para. II.
} 
The Commission's reluctance to impose rules in this area is understandable in view of its earlier decisions (which have been ratified by the Supreme Court) that CATV is not a common carrier. However, it is now obvious that the rationale of those decisions is no longer valid.

In 1958 , the FCC decided that CATV systems are not common carriers under Title II of the Communications Act of $1934 .{ }^{88}$ That decision acknowledged that CATV systems have "several attributes in common with the operation of a communications common carrier, particularly to the extent that there is an offer to transmit, by wire, intelligence in the form of television broadcast signals, to any member of the public who desires to subscribe to the service." ${ }^{\text {" } 9}$ Yet, the FCC found a distinction between CATV and traditional common carrier services in that the CATV operator has the ultimate and final choice of the signals to be carried over the system: the subscriber can only choose between the signals offered. The subsequent development of CATV regulation, however, has eliminated this distinction. The FCC's carriage and major-market/distant-signal policies have removed much, if not practically all, of the CATV system operator's discretion and prerogative over what specific signals are to be received and carried. Even the Commission acknowledges this: "While CATV operators select the signals carried (within the confines of the applicable Commission rules), they generally have no control over the content of the communications on the signals selected." ${ }^{\prime \prime}$ Moreover, CATV "has tended to develop on a non-competitive monopolistic basis in the areas served, so that only one cable enters the subscriber's premises." 191 This monopoly tendency is exacerbated by the likely fact that subscribers will not utilize their sets to receive over-the-air signals. When one considers the important communications role of broadcasting, it becomes apparent that it is vital that persons other than those engaged in broadcasting have access to this medium.

Given these considerations, it behooves the FCC to re-evaluate the 1958 Frontier decision and to project, on a long-term basis, whether the ultimate role of CATV should be as a common carrier. The legal rationale for the contrary conclusion no longer has merit since CATV clearly falls within not only the statutory definition but also the Commission's own articulation of principles establishing what is a common carrier. Application of Title II to this industry would give the FCC greater flexibility in devising and continually updating rational communications policy which in this day of rapidly expanding technology is vital. Moreover, the assertion of common carrier jurisdiction could be accomplished without Congressional action.

\footnotetext{
${ }^{88}$ Frontier Broadcasting Co., 24 F.C.C. 25 I (I958).

${ }^{80}$ Id. para. 8. With this holding should be compared the statutory definition of a common carrier: " 'Common carrier' or 'carrier' means any person engaged as a common carrier for hire, in interstate or foreign communication by wire or radio or in interstate or foreign radio transmission of energy, except where reference is made to common carriers not subject to this chapter; but a person engaged in radio broadcasting shall not, insofar as such person is so engaged, be deemed a common carrier." 47 U.S.C. $\S x_{53}(h)\left(\mathrm{I}_{964}\right)$.

00 CATV Amendments (First Report and Order), supra note 9, para. I3.

${ }^{01}$ Id. para. 15.
} 
The history of legislative inaction in the face of continued FCC requests for guidance gives little hope that any definitive alteration of the Communications Act will be enacted, and therefore it is incumbent on the Commission to obtain the maximum appropriate regulation from existing statutory provisions.

The real public advantage that could evolve would be the establishment of a number of channels of communication which would be available to the public generally for communications purposes at relatively moderate cost. Moreover, one of the main economic arguments against CATV-the problem of serving rural areas-could be resolved, over a period of time, administratively by applying the same principle that has been used so successfully in extending telephone servicethat is, by establishing a rate of return on total fixed investment rather than pricing services on the basis of the incremental cost of providing them. The same rationale could be utilized by requiring different rates for persons with poverty level incomes. While it could be argued that this would be discriminatory, such differentiation could be justified.

Moreover, aside from the All-Channel Receiver legislation, the only major innovation that Congress has been prepared to adopt in communications legislation was the Communications Satellite Act, ${ }^{02}$ which involved a novel distribution system. This would be a precedent for requesting Congress to adopt ways of inducing investment in cable installation in areas that are not economically feasible under existing cable financing methods. Alternatively, the telephone common carriers could perhaps be induced (and permitted) to wire homes in areas not sufficiently dense to attract venture capital. ${ }^{93}$

If all CATV operations were to be designated as common carrier, the offshoot could be an eventual separation of the program creation function from the program transmission function. The basic product of any television station is the programs it produces or obtains. The transmission of the product to the viewer is a mechanical or transport function not necessary to the former. In virtually every other industry, the manufacturer relies on common carriers (railroads, trucks, and so forth) to transport its product to the consumer. This distribution method did not evolve in broadcasting because of the lack of transport facilities; therefore, broadcasters were required to develop their own facilities (such as transmitters and antennas). The advent of CATV, however, provides an opportunity for long-term policy planning to separate the two functions in the broadcast industry. In fact, even now the major program sources (the television networks) do not themselves transmit their products but rely on the facilities of the communications common carrier to distribute their products to affiliated stations.

There are a multitude of possibilities inherent in separating the programming

\footnotetext{
${ }^{02} 47$ U.S.C. $\$$ 70I et seq. (1964).

${ }^{\circ 3}$ At the end of $1968,82 \%$ of all U.S. farm homes were equipped with telephones, and there wcre 51.8I telephones in use for every 100 people in the United States. Telephony's Directory op the TELEPHONE INDUSTRY (1969).
} 
from the transmitting function. For example, certain channels could be leased to commercial broadcasters at a rate that would reduce the cost to the subscriber, or at least make it so nominal as to be available to all. The present broadcast industry would, for the most part, be unchanged except that it would not require transmitting apparatus. In fact, so reducing the cost of entry could well attract more capital and entrants than would be the case under a continuation of the present system. ${ }^{94}$ Since a major element of the expense of establishing a television station is the cost of the transmitting apparatus, the availability of leased channels for the transmission function could result in a proliferation of broadcast services. CATV operators would be relieved of the burden of developing a capacity to originate, and broadcasters would be relieved of concern for technical transmission problems. The states (or their political subdivisions) which already have exercised substantial authority over $\mathrm{CATV}^{95}$ could assume a part of the regulatory burden-such as establishing rates. Perhaps most important, the frequency spectrum now occupied by VHF and UHF channels could be devoted to other pressing needs.

\section{CONCLUSION}

The pending rule-making proceedings would make an ideal vehicle for a full evaluation of the role of CATV and over-the-air broadcasting in the context of a separation of the transmission function (CATV) from the programming function, which is the basic area of expertise of the broadcaster. The visionary prospects for CATV will be difficult, if not impossible, to realize if it continues in a supplementary role to broadcasting. Relieving CATV of the problem of being concerned with what is actually transmitted over its facilities would leave it free to develop new services and techniques. Moreover, the FCC, which has accomplished much in a legislative vacuum, could restructure communications policy under existing law if, after rule making, separation of function seemed economically feasible and if its accomplishment were possible without causing undue economic loss to those who have committed their capital in reliance on existing policies. As the rule-making procedure has not ended, there is a continuing opportunity for investigation of these matters. At least the events of recent years, characterized by FCC uncertainty about long-range policy, do not make steps in the direction indicated seem beyond the realm of possibility.

\footnotetext{
${ }^{\text {os }}$ The economic considerations summarized in this paper are based on the exhaustive evaluation of the wired city concept in Barnett \& Greenberg, supra note 5. See also Barnett \& Greenberg, Regulating CATV Systems: An Analysis of FCC Policy and an Alternative, in this symposium, p. 562.

${ }^{\circ 5}$ See Witt, CATV and Local Regulation, 5 CaLIF. W.L. Rev. 30 (I968).
} 